\title{
LEAN MENEDZSMENT ALKALMAZÁSA EGY ÉPÍTŐIPARI PÉLDÁN KERESZTÜL
}

\author{
Gáspár Sándor - Thalmeiner Gergő
}

\begin{abstract}
Absztrakt: Hazánk egyik nagy problémája a termelékenység alacsony szintje. Ez az alacsony szint pedig kiemelkedően alacsony a Kis-közép vállalkozások körében. A régiós országokban és a nyugateurópai országokban ezen méretű vállalkozások átlagos termelékenységi szintje magasabb mint hazánkban. A most és várhatóan a közeljövőben is jelenlévő munkaerőhiányos környezet a vállalkozásokat választás elé állítja. A bérnövekedést hosszútávon kizárólag a termelékenység növekedésével lehet elérni. Az a szervezet, amelynél nem nő a termelékenység az alul marad mind a hazai mind a nemzetközi-globális versenyben.

A hazai kis és középvállalkozások termelékenység és versenyképesség növelésének egyik kulcs eleme lehet a modern gazdálkodás szervezési és menedzsment rendszerek alkalmazása, amelyek közül kiemelendő a lean menedzsment alkalmazása. Nagyon sok olyan iparágban, ahol projektgyártás folyik a lean eszközökre és módszerekre másként és nem alkalmazható eszköznek és módszernek tekintenek, de ez nem feltétlenül van így. Ezekben az iparágakban is kiválóan alkalmazhatóak ezek a rendszerek és drasztikus javulást lehet elérni a termelékenység tekintetében.

Kutatásunkban az építöipari folyamatokat, azon belül is a gipszkartonépítési folyamatok értékfolyamat térképezését és mudák kiküszöbölését vizsgáljuk. Kifejezett hangsúlyt fektetünk az átfutási idő illetve a termelékenység növekedésének vizsgálatára, amelyet egy gipszkartonépítéssel foglalkozó vállalkozás példáján keresztül szemléltetünk.
\end{abstract}

\begin{abstract}
One of the major problems in Hungary is the low level of productivity. This low level is extremely low among small-medium businesses. In the countries of the region and in Western European countries, the average productivity level of enterprises of this size is higher than in Hungary. The current and expected short-term labor shortage environment puts businesses at the forefront. In the long run, wage growth can only be achieved through increased productivity. An organization with no increase in productivity remains at the bottom of both domestic and international-global competition.

One of the key elements in increasing the productivity and competitiveness of small and mediumsized enterprises in Hungary can be the use of modern management organizational and management systems, of which the use of lean management should be emphasized. In many industries where project production is going on for lean tools and methods, it is considered differently and not an applicable tool and method, but it is not necessarily the case. These systems are also well suited to these industries and drastic improvements in productivity can be achieved.

In our research we examine the construction processes, including the mapping of the value process of plasterboard construction processes and the elimination of mud. We put a strong emphasis on examining the growth of lead time and productivity, as illustrated by an example of a plasterboard company.
\end{abstract}

Kulcsszavak: lean, vsm, folyamatmenedzsment, veszteség feltérképezés

Keywords: lean, vsm, process management, loss mapping

\section{Bevezetés}

Az 1980-as években a világ figyelme a Toyotára irányult, azért mert ekkora vált világosság hogy a japán minőség és hatékonyság teljesen egyedülálló a világon. A japán autók megbízhatóbbnak, tartósabbnak bizonyultak, mint az amerikai gépjárművek (Liker, 2008). 1990-re az is nyilvánvalóvá vált, hogy a japán gyártók közül is kiemelkedik egy autógyártó mégpedig a Toyota. A Toyota megbízhatóbban, 
gyorsabban mégis versenyképes költségek mellett készített és tervezett autókat mindezt úgy, hogy viszonylag jól fizetett munkásokat alkalmazott. Jelenleg a Toyota egyértelmủen a világ legnyereségesebb autógyártója a világon (Rother, 2014).

\subsection{Lean Szemléletmód}

A lean szemlélet segítségével meg lehet határozni, hogy mi az érték. Csakis a végfelhasználó az, aki eldöntheti, hogy mi számít értéknek, és csak akkor lehetséges érdembe értékröl beszélni, hogyha egy adott termék az adott áron és időben kielégíti a vevő igényeit. Az értéket a gyártó teremti meg (Shigeo, 1989). A lean szemlélet segítségével optimális sorrendbe lehet állítani azokat a müveleteket és folyamatokat, amelyek értéket teremtenek, és ezeket a megfelelő időben, a megfelelő helyen, a megfelelő mennyiségben, megszakítás nélkül egyre hatékonyabban lehessen elvégezni. A lean szemlélet nem állhat meg egy cég határánál, hanem azon tovább kell terjednie (Womack - Jones, 2003).

A lean management öt alapelve:

- az érték meghatározása

- $\quad$ az értékfolyamat azonosítása

- az áramlás létrejötte az értékteremtő lépések mentén

- húzóelv alkalmazása

- tökéletesítés, folyamatos fejlesztés

\subsection{Muda}

Ahhoz hogy megértsük a lean lényegét elöször meg kell ismerkednünk azzal a japán szóval hogy muda. A muda szó „,veszteséget” jelent, azaz minden olyan emberi tevékenységet, amely erőforrást használ fel, de nem teremt értéket. Annak ellenére, hogy a vevő csak azért hajlandó fizetni, ami számára értéket jelent, a folyamatok elemeinek (tevékenységek, müveletek, müveletelemek, mozdulatok) jelentős része nem termel értéket (Liker, 2008).

Taaichi Ohno eredetileg hét darab muda típust azonosított a fizikai termelésre általánosan jellemző vesztségekről:

a) Túltermelés: a termékekből, illetve szolgáltatásokból nagyobb mennyiséget állítunk elö, mint azt a vevők igényelnék

b) Várakozás: várakozási idök ott jönnek létre, ahol az alkalmazottak vagy a gépek a munkafolyamat vagy munkaterület adottságai, illetve a tervezési és irányítási problémák miatt tevékenységeik és müveleteik elvégzésében akadályozva vannak, és ezalatt a szükséges és elvégzendő tevékenységeket nem tudják elkezdeni

c) Felesleges szállítás: anyagok felesleges szállítása (pl: részlegek illetvel az egyes létesítmények között)

d) Technológiai veszteség: alkatrészek előállításakor jelentkező veszteség, amely a rosszul tervezett eszközöknek és termékeknek köszönhető

e) Készletek: abszolút minimumot meghaladó készlet

f) Felesleges mozgások: az alkalmazottak munkavégzésük során fellelhető felesleges mozgások 
g) Selejt termelése: hibás termék vagy szolgáltatás előállítása, és a hiba utólagos észrevétele, végül a hiba kijavítása (Ohno, 1988).

\subsection{Vsm (Value stream mapping)}

A VSM vagyis értékfolyamat térkép egy stratégiai eszköz, amely által azonosíthatóvá válnak a veszteségek. Az értékfolyamat térképet több szakirodalom értékáramtérképnek szokott nevezni. A Toyotánál anyag és információáramlási diagram néven ismert módszer egy változata (Schwahofer - Kosztolányi, 2015).

A VSM segítségével:

- az értékfolyamat térképezés alkalmazásával láthatóvá válik az anyag és információáramlás teljes folyamata, a beszállítótól kezdve egészen a vevőig

- észre lehet venni olyan veszteségeket, amelyek az egyes folyamatokra koncentrálva nem lennének láthatóak

- a termelési rendszert jobban és mélyebb szinteken lehet megismerni és vizsgálni

- $\quad$ szigetszerü alkalmazás helyett lehetővé válik a lean eszközök strukturált alkalmazása

- a folyamatokat az értékteremtés szemszögéből lényeges sorrendben lehetséges ábrázolni

- könnyebbé válnak a fejlesztési projektek megvalósítási sorrendjének kialakítása illetve meghatározása

- egyszerübbé és könnyebbé válik a kommunikáció a termelési rendszerrel kapcsolatos kérdésekben (Schwahofer - Kosztolányi, 2015)

$\mathrm{Az}$ értékfolyamat térképezés sikeresen alkalmazható a termelési és tervezési folyamatok feltérképezésére. Viszont a szolgáltatási folyamatok feltérképezése során is sikeresen lehet implementálni, elsősorban a gyakran ismétlődő repetitív adminisztratív folyamatok ábrázolására vizsgálatára, elemzésére és fejlesztésére (Hines - Rich, 1997).

A térképezés lépései:

Termék család kiválasztása során figyelembe kell venni, hogy egy adott üzemben legtöbbször számos terméktípust gyártanak, melyek egymástól teljesen eltérő folyamatokon illetve müveleteken haladnak, áramlanak át. Ahhoz hogy egy átlátható térképet megvalósíthassunk, az szükséges hogy bizonyos kompromisszumokat kell kötni. Az első ilyen kompromisszum hogy egy térképen nem lehet ábrázolni többet egy termékcsaládnál, mert a térkép átláthatatlanná válik, és akkor már nem tudja betölteni a feladatát (Faulkner - Badurdeen, 2014).

Általánosan elfogadott ökölszabály, hogy azokat a termékeket lehet egy termékcsaládba sorolni, amelyekre az jellemző, hogy:

- az egyes müveleteken belül a rájuk fordított munkamennyiség maximum 30\%-ban tér el egymástól

- közel 80\%-ban ugyanazokon a müveleteken haladnak keresztül

Miután meg lett határozva az ábrázolandó termékcsalád, szükségessé válik az információk begyüjtése, a jelen állapot térkép elkészítése. A térképezés a beszállítótól a vevőig tart, de a fö fókusz a termelési folyamatokra helyeződik. A 
beszállítókat és a vevőket is csak ezekhez való kapcsolódásuk miatt lehet ábrázolni. Itt is igaz az, mint a lean módszerek alkalmazására általában, hogy itt sem kell annak az elsődleges célnak lennie, hogy az információk 100\%-t már a jelenállapot felvétele során megszerezzük. Ennél a lépésnél kiemelt szerepet játszik, hogy a térképezés egyetlen célja a fejlesztés lehessen, mert önmagában a térkép elkészítésével nem tudjuk növelni a hatékonyságunkat (Singh et al. 2011).

Ha már meg van rajzolva a jelenállapot térkép, akkor következhet a térképen a problémák ábrázolása. Ezek a problémák azok, amelyek akadályozzák a hatékony anyag és információáramlást, illetve ezek a problémák azok, amelyek eltérnek az ideális termelési rendszertől és az elvárt állapottól.

Amennyiben már lehet látni, hogy hogyan müködik a termelési rendszer és azt is, hogy mely fö problémákkal kell szembenézni, akkor el lehet kezdeni a jövőállapot térkép elkészítését. Ez azt fogja megmutatni, hogy milyennek, kell lennie a termelési rendszernek, hogy hatékonyan müködjön a rendszer.

A legalaposabban megrajzolt térkép sem lesz aktuális túl sokáig, mert folyamatok napról napra változhatnak. Ez az elsődleges oka, hogy a jövőállapottérkép megrajzolása után a lehető leghamarabb neki kell kezdeni az akciólisták megírásának, és a megvalósítást is rövid időn belül meg kell kezdeni. A szokásos feladat-felelős-határidőn kívül meg kell határozni az adott feladatok célját és azoknak a mérési módszereit is (Schwahofer - Kosztolányi, 2015).

\section{Anyag és módszer}

A kutatásunk során az volt a célunk, hogy megpróbáljuk minél jobban törekedni az interdiszciplináris jellegre. Ahhoz, hogy a kutatás megfelelő legyen és megfeleljen a tudományos kritériumoknak és egy viszonylagos rálátást nyerjünk a vállalkozási folyamatok megismerésére és képesek legyünk elemzni őket, szükségünk volt a vállalkozások tulajdonosaival és projektmendzsereivel mélyinterjút készíteni. Ezen mélyinterjúk mind strukturált mélyinterjú volt. Ez azért volt szükséges, hogy a különböző válaszok összehasonlíthatóvá válhassanak és ezáltal megvalósítsuk a standardizáltságot. Az elkészített mélyinterjúk száma három darab volt. A folyamat elemzés viszont alapvetően egy darab vállalkozás folyamat elemezéséröl szólt mivel ezen cég volt az, amely átalakította a folyamatait a lean eszköztár felhasználásával. A többi vállalkozás interjúi a gipszkarotnfal építés hagyományos nem lean alapú megközelítés megismerésében és feltérképezésében segítették munkánkat (Babbie, 2008).

\section{Gipszkartonfal építés értékfolyamat feltérképezésének eredménye}

Mivel a gipszkartonfal építés egy projektgyártású tevékenység, ezért kizárólag megrendelés alapján történik a kivitelezés. Ez a tény azt a változtatást okozta a folyamatrendszerü értékfolyamat térképezéséhez képest, hogy a vevők általi megrendeléseket nem lehet mennyiségben és időrendben kiszámítani, és a megrendelések specializáltsága, illetve a kivitelezés helyszíne is sok változtatást igényel a kivitelezés technológiájában. Állandó rendelési mennyiséget sem lehet 
felállítani a vizsgált vállalkozások esetében, ezért a vevői igényekhez a cég által elmondott egyes megrendelések nagyságának az átlagát írtuk a feltérképezés során, amelynek a mértékegysége négyzetméter.

A vállalkozás a gipszkartonfal építéséhez szükséges alapanyagokat kizárólag egy építőanyag kereskedő partnerétől szerzi be. (Ennek az az oka, hogy ez az alapanyag kereskedő partner $250 \mathrm{~m}^{2}$ kartonfal építéséhez szükséges alapanyag után nagymértékü kedvezményt nyújt a vállalkozás számára.) Az alábbiakban az értékfolyamat térképen az alapanyagokat nem teljesen részletezve, hanem a négy leghangsúlyosabb (az alapanyagok és készletek 90\%-át kitevő) csavarokat, gipszkartonlapokat, festékeket és profilokat, hőszigetelő anyagokat ábrázoltuk. Egy darab vagy egy $\mathrm{m}^{2}$ egységnyi készlet illetve alapanyag (cs, g f, $\mathrm{p} \mathrm{h}$ ) csak megközelítő mivel egy $\mathrm{m}^{2}$ gipszkartonfal építéséhez szükséges alapanyag nem egy konstans érték, ezért nem teljesen pontosak, hanem átlagolt illetve a tulajdonos elmondása alapján megbecsült értékeket alkalmaztunk (Steyer, 2018).

\subsection{Térképeken feltüntetett jelölések, rövidítések magyarázata}

- Ciklusidő (CT-cycle time): egy termék elkészítésnek időszükséglete

- Átállási idő (CO-change over time): gépek átállási ideje egy másik munkafolyamatra egy adott technológián belül (például csavarozógép „fejének" átállítása egy másik méretü csavarhoz)

- Létszám: megmutatja az adott gépsoron, illetve technológiával dolgozó operátorok számát

- Termelési idő: ez az időtartam magába foglalja a müszak hosszából levont szüneteket és egyéb tervezett megállásokat, leállásokat (Kosztolányi Schwahofer, 2012).

\section{1. ábra: Jelmagyarázat}

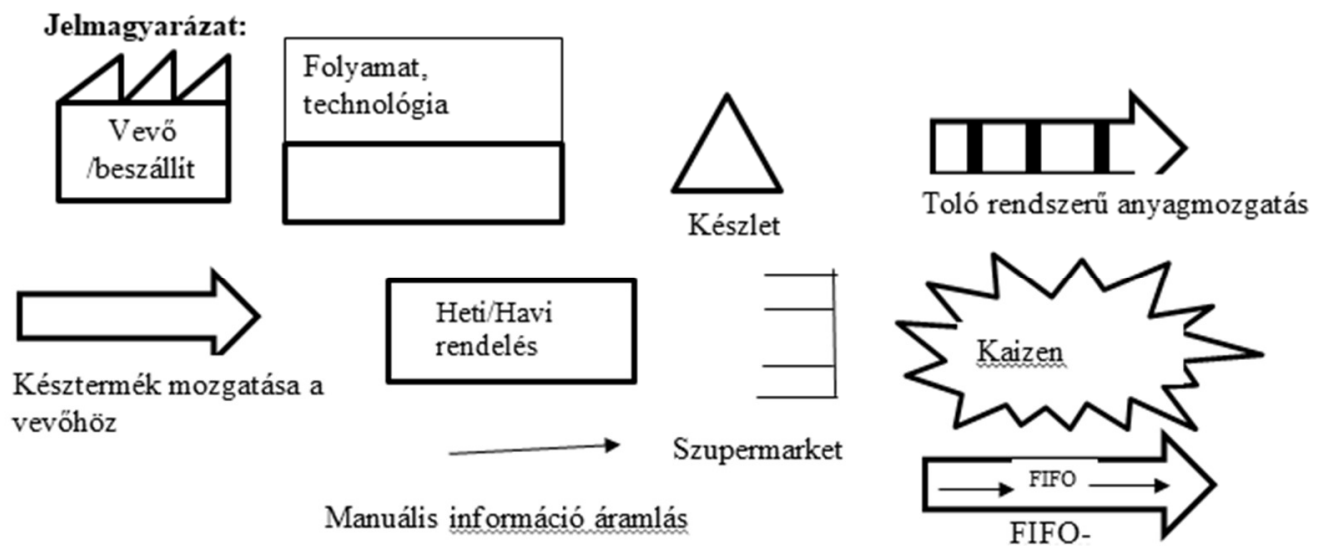

Forrás: A szerzők saját szerkesztése/ Kosztolányi J. - Schwahofer, G. (2012) alapján

A térkép alján azt fogjuk jelezni, hogy az egyes folyamatok illetve technológiáknak mennyi az értékteremtő ideje. Mivel a cég nem tudta pontosan meghatározni ezt az 
időt, ezért csak megközelítő értékeket fogunk alkalmazni az értékteremtő idő meghatározására.

A folyamatok illetve technológiák között pedig azt fogjuk jelezni, hogy mennyi időt kell várnia egy-egy adott technológiának ahhoz, hogy a másik technológia elkészülhessen, ez az idő már tartalmazza az értékteremtő időket is. A maradék várakozás az alkalmazottak felesleges tevékenységeiből, az elöre tervezett elvégzendő idő kicsúszásából, információ és anyag hiány miatt jön létre. Ezek a számok átlagolva és becsülve vannak egy-egy munkálatra levetítve a tulajdonos segítsége által (Steyer, 2018).

A termelés illetve kivitelezés ütemezése manuális módszerrel müködik a vállalkozásnál, tehát vagy a projektmenedzser, illetve a müvezető saját maguk számolják meg a készleteket és alakítják ki a termelési-kivitelezési utasításokat.

A 26400 s müszakidő pedig úgy jött ki, hogy napi 8 óra 20 perc munkaidőből 20 perc az ebédszünet és a tulajdonos engedélyével pedig minden órából 5 percet „,cigaretta” szünettel töltenek az alkalmazottak (Matuz, 2018). 


\subsection{Jelenállapot térkép meghatározása}

\section{2. ábra: Jelenállapot térkép}

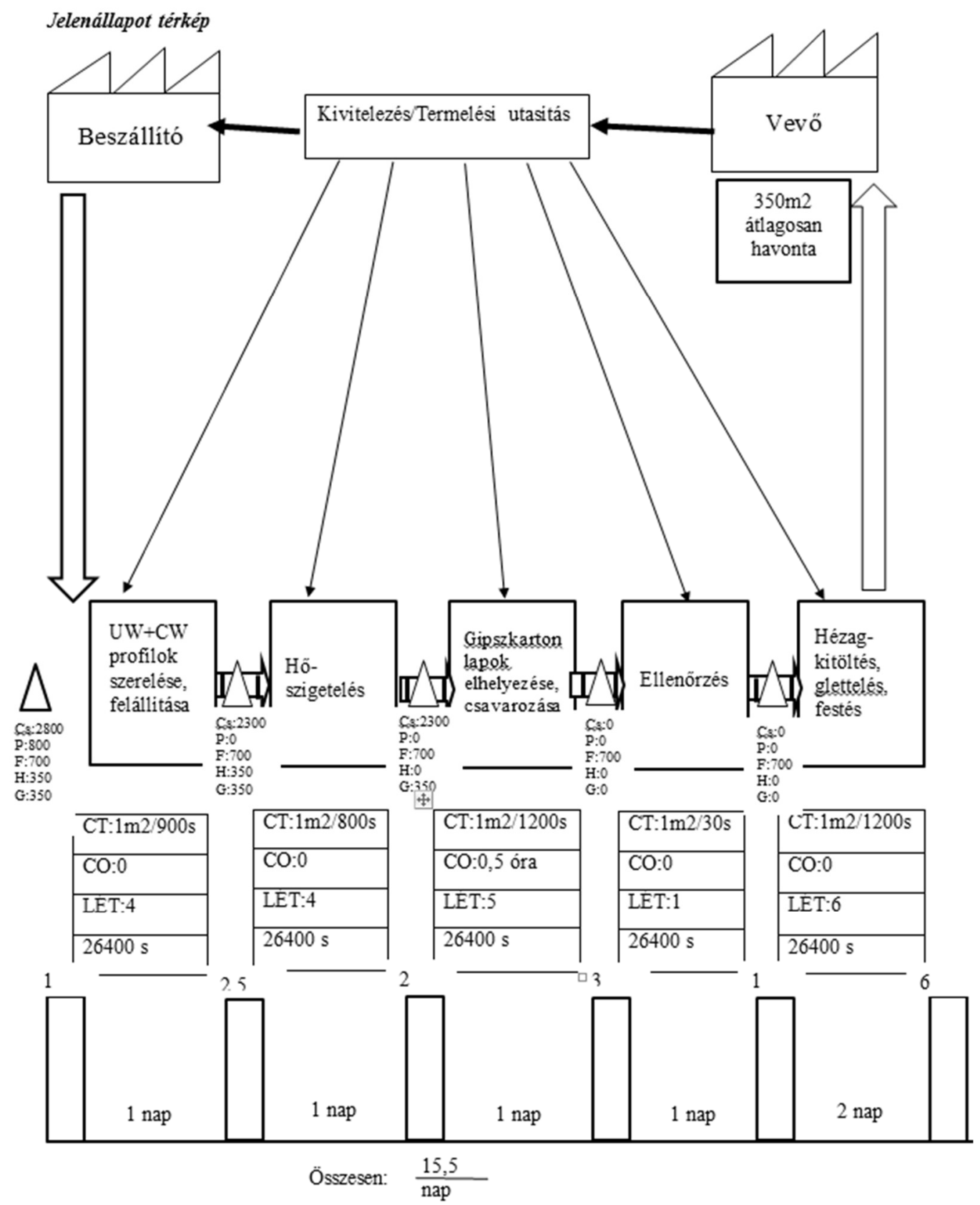

Forrás: A szerzők saját szerkesztése/ Kosztolányi J. - Schwahofer, G. (2012) alapján

\subsection{Problémák feltüntetése a térképen}

Az első észrevett probléma az volt, hogy a gipszkarton elhelyezés és csavarozásnál megjelenik a csavarozógép átállása, illetve az új csavarok előkészítése, amely a 
tulajdonos elmondása alapján átlagosan fél órát vesz igénybe, de egyes speciális esetekben ez akár több is lehet.

A másik észrevétel, hogy az ellenőrzés a lean gondolkodás szerint egy értéket nem teremtő felesleges tevékenység. A vizsgált vállalkozás azért alkalmazta, mert szeretné megelőzni azt a problémát, amely már többször is felmerült a kivitelezéseik során. Már a hézagjavítás, glettelés, festés folyamatai után merült fel probléma és a tulajdonos elmondása szerint sokkal nagyobb veszteséget okozott számukra, ennek elkerülése érdekében megérte beiktatni ellenőrzési pontokat. Az ellenőrzéssel kapcsolatosan még az az észrevételünk, hogy ez egy olyan szük keresztmetszet, amelynél a festékek mind készleten állnak, és az alkalmazottak sem végeznek értékteremtő feladatokat.

A harmadik észrevételünk a felesleges készletezéssel függ össze, amely a lean egyik alapelve is. Véleményünk szerint jelen esetben a höszigetelés egy olyan tevékenység, amelynek elvégzése nem igényel speciális gépparkot, és amíg elvégzik a tevékenységet addig a gipszkartonlapok és csavarok feleslegesen állnak készleten, valamint a legnagyobb helyet is veszik igénybe a készletek között.

Az utolsó észrevételünk pedig az, hogy az utolsó tevékenységet követően, a hézagjavítás, glettelés és festés után van egy hat órás száradási idő, amely a leghosszabb várakozási idő a tevékenységek alatt.

Mivel itt egy kifejezetten projekt alapú tevékenységről van szó, ahol nem már meglévő gépeken dolgozó munkatársak végeznek operációkat, ezért itt a push rendszerről pull rendszerre váltás nem lehetséges, vagyis nem valósítható meg érdemben a húzórendszer (Steyer, 2018).

Az első egy nap az alapanyagok helyszínre szállítását és pakolását- rakodását, és rendszerezését foglalják magába. Mivel ez sem teremt értéket a vállalkozás számára, ezért ez is egy muda, de ezzel a vállalkozás önmagában nem tud mit kezdeni, viszont azt megcsinálta, hogy jobban szervezi a pakolást és raktározást, bár ez ennek az egy napnak csak körülbelül a 20\%-át teszi ki. Ahhoz, hogy a $80 \%$ szállítási és pakolási folyamat hatékonyabb lehessen, egy másik beszállítóra kellene váltania a cégnek, de a váltás nem érné meg számukra, még így sem hogy egy teljes napnyi mudát „termel” a vállalkozás (Matuz, 2018). 


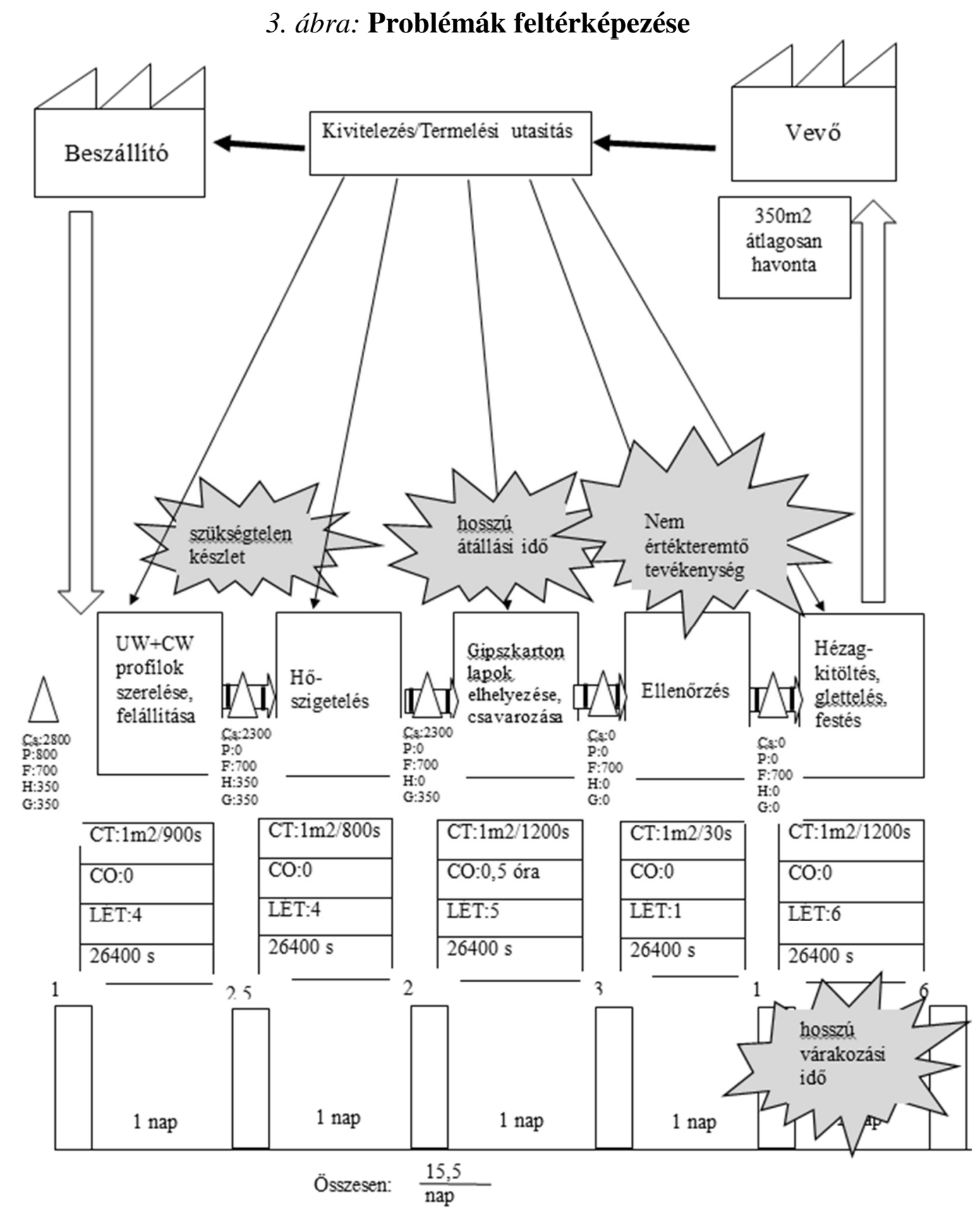

Forrás: A szerzők saját szerkesztése/ Kosztolányi J. - Schwahofer, G. (2012) alapján

\subsection{Jövőállapot-térkép}

A jövőállapot térkép jelölései és formális kinézete ugyanaz lesz, mint az előző két térképé csak itt már az az állapot lesz ábrázolva, ahogy megoldható módon át lett szervezve a rendszer, vagyis itt már a vállalkozás hatékonyabb és termelékenyebb állapota látható. 
A hosszú átállási idő csökkentése a gipszkartonlapok elhelyezésénél és csavarozásánál nem valósítható meg csak egy újabb csavarozógép bevonásával, amely segítségével már két ember tudna csavarozni, és mindkettő külön géppel különböző típusú csavarokat. Az alábbi jövőállapot térképen ezt nem fogjuk jelölni, mivel ennek a beszerzéséhez jelentősebb összeg szükséges és jelenleg a vállalkozás ezt nem tudná finanszírozni.

A második problémára az ellenőrzésnek, mint nem értékteremtő tevékenységnek a beintegrálása a legjobb megoldás. Láthatóvá vált, hogy az ellenőrzést már a gipszkarton lapok elhelyezése és csavarozása után, részegységenként közvetlenül végeznék. Ebben az esetben jóval gyorsabbá vált az ellenőrzési folyamat, és nem jelent meg nagymértékü mudaként a müveletek során. Ugyanakkor a végső cél egyértelmüen egy olyan rendszer kialakítása, amely teljesen kiszüri és lehetetlenné teszi a hibázás lehetőségét, ezáltal az ellenőrzés, mint tevékenység és funkció azonnal értelmét vesztené.

A harmadik akadályra leghatékonyabb megoldásként bizonyult az, hogy a höszigetelést az elötte lévő profil felállítási folyamatok után egységenként és közvetlenül valósul meg. Ez technológiailag kivitelezhető volt mivel a hőszigetelő anyag elhelyezéséhez nem szükséges speciális technológia és különösebben nehéz szaktudás sem. Ezáltal a vállalkozásnak a hőszigeteléshez szükséges alapanyagai tárolásának ideje is lerövidült, és egyben lerövidült a munka teljes elvégzési ideje is.

Az utolsó észrevételünk pedig, hogy a legvégső festék száradási hat órás hosszát drasztikusan le kéne csökkenteni. Ez a legnagyobb várakozási muda a rendszerben, mert ilyenkor már a dolgozók sem tudnak értéket teremteni, és már következő folyamat illetve müvelet sincs. Véleményünk szerint, ha ezt egy kaizennel vagy esetleg akár egy kaikauval képesek lennének drasztikusan csökkenteni, akkor óriási hatékonyság növekedést érhetnének el. A tulajdonos elmondása szerint léteznek olyan festékek, amelyeknek fele annyi idő a száradási idejük, viszont drágábbak, ugyanakkor nem biztos, hogy annyival többe kerülne ezen típusú festékek használata, hogy ne érné meg inkább ezekkel festeni. Az alábbi jövőállapot térképen azzal kalkulálunk, hogy egy ilyen festék típust alkalmazva fele annyi időre csökkenthető a hat órás várakozási muda. A végső cél itt is az lenne, hogy valamilyen módszerrel vagy technológiával nullára csökkentse ezt az időt a vállalkozás (Matuz, 2018).

Ahhoz hogy a müveletek és folyamatok idejét drasztikusan csökkentsék, bevezették ahol csak lehetett a FIFO rendszert. Valamint, ahhoz hogy a vállalkozás hatékonyan tudja müködtetni az alábbiakban felrajzolt rendszert a munkaerö bővítésére és hatékonyabb elosztására is szükség volt. (Eddig egy dolgozó két müveleten illetve technológián is dolgozott egyes esetekben, mert időben egymás után következtek, de az alábbiakban össze lettek vonva, így már egy dolgozó nem tud két müveleten is dolgozni.) (Steyer, 2018). 


\section{4. ábra: Jövőállapot térkép}

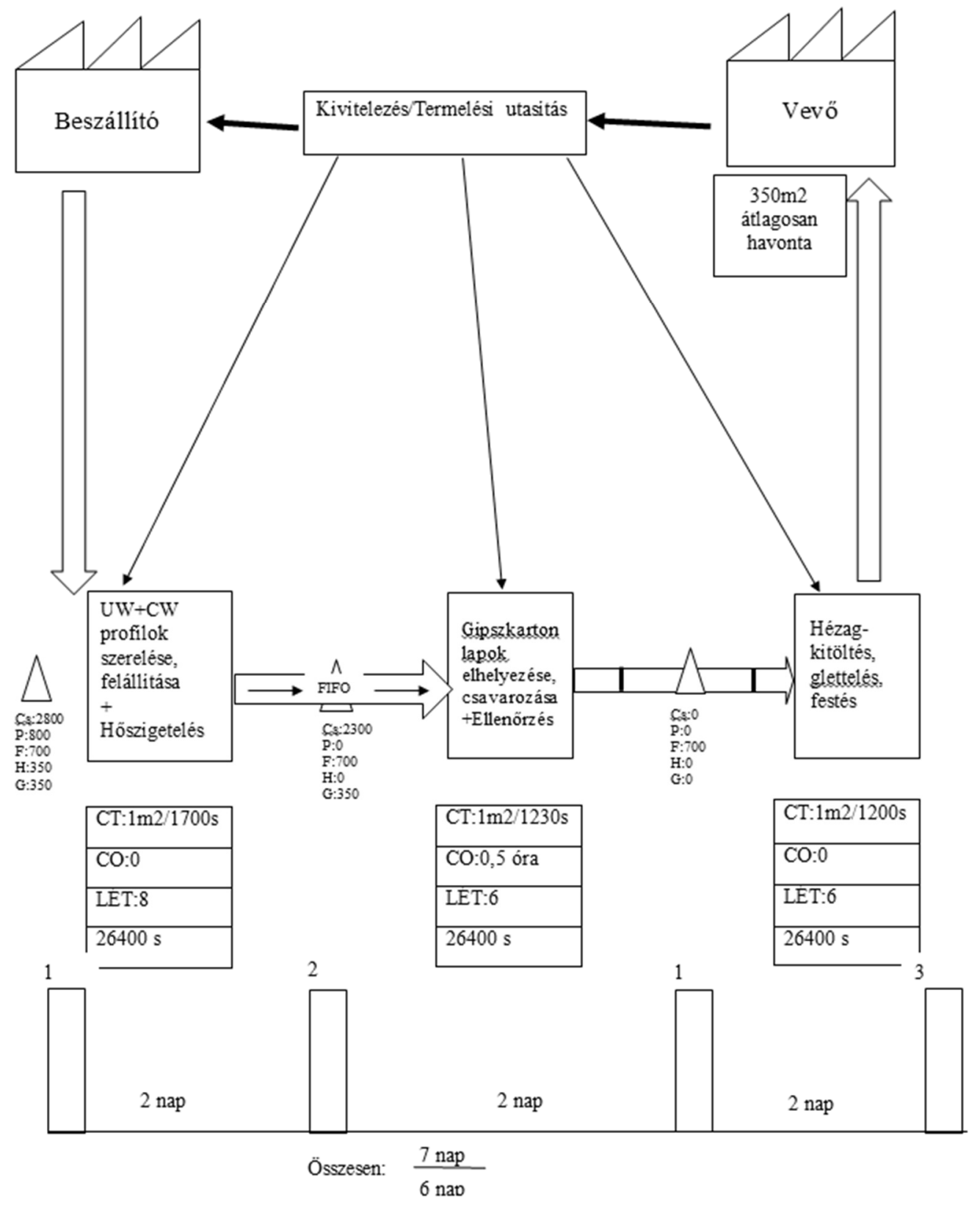

Forrás: A szerzők saját szerkesztése/ Kosztolányi J. - Schwahofer, G. (2012) alapján

\section{4. Összefoglalás}

Egyértelműen le lehet vonni azt a következtetést a fenti elemzésből, illetve folyamat optimalizálásból, hogy a lean eszközöket és módszereket, de azon belül pedig kiemelten az érték térképezést és az ezáltal megvalósuló „tisztán látást” és az azzal járó teljesítmény, illetve termelékenység javulás teljesen jól implementálható a projekt alapú gyártási tevékenységek esetében is. 
A fentebb bemutatott átalakított termelési rendszer kiválóan szemlélteti, illetve bemutatja azt a teljesítmény növekedési potenciált, amely a lean eszközök és módszerek alkalmazásában állnak. A tanulmányban elemzésre kerülő cég az értéktérképezés és az azzal járó optimalizálási átszervezett folyamatok segítségével 8,5 nappal csökkentette az átlagos átfutási idejét.

A vállalkozás jelenleg még nem alkalmazza minden tekintetben a lean eszközöket és módszereket, tehát a teljes, holisztikusan megjelenő hosszú távú termelékenység és ezáltal versenyképesség növekedést még nem lehet látni, csak annak részeredményeit.

Hazánkban az építöiparban, de nagyon sok más szektorban is, ahol a kis-közép vállalkozások száma és piaci részaránya domináns a lean eszközök és módszerek alkalmazása egyértelmüen versenyelőny forrásként szolgál. Megállapítható, tehát, hogy az a szervezet, amely gyakorlatiasan tudja alkalmazni ezeket a lean eszközöket és módszereket, komoly termelékenység szintbeli növekedést ezáltal pedig versenypozíció erősítést- előnyszerzést érhet el.

\section{Irodalomjegyzék}

Babbie E. (2008): A társadalomtudományi kutatás gyakorlata, Budapest, Balassi Kiadó 336-342

Faulkner, W. - Badurdeen, F. (2014) Sustainable Value Stream Mapping (Sus-VSM): methodology to visualize and assess manufacturing sustainability performance, Journal of Cleaner Production. (85) 8 -18.

Kosztolányi J. - Schwahofer, G. (2012). Értékfolyamat térképezés, KaizenPro Oktató és Tanácsadó Kft. Budapest. 55-62.

Liker, J. K. (2008). A toyota módszer. HVG-kiadó, Budapest. 15-34, 43-48.

Matuz, S. (2018). Lean menedzsment bevezetése a Mester és Társa Kft gipszkartonfal építési folyamataiba, Budapest. Interjú (Gáspár S.- Thalmeiner G. Kérdezők)

Ohno, T. (1988) Toyota Production System: Beyond Large-Scale Production. New York, Productivity Press 48-62.

Schwahofer, G. - Kosztolányi, J. (2015). Lean Szótár, LeanPro Kft. Budapest 39-45.

Shigeo, S. (1989) A study of the Toyota Producting System From an Industrial Engineering Viewpont, Cambridge, Productivity Press (1) 32-37

Steyer, F. (2018) Gipszkartonfal építési munkálatok és folyamatok, Mester és Társa Kft. Budapest, Interjú (Gáspár S.- Thalmeiner G. Kérdezők)

Singh, B. - Garg S. K. - Sharma K. (2011) Value stream mapping: literature review and implications for Indian industry. The International Journal of Advanced Manufacturing Technology. (53) 799-809.

Rother, M. (2014). Toyota-Kata. HVG-könyvkiadó, Budapest 30-41.

Womack, J. P. - Jones, D. T. (2003). Lean szemlélet. HVG-kiadó, Budapest 67-80, 83-89. 